\title{
Occupational risk factors of contracting COVID-19 among health workers: A systematic review
}

\author{
Haizhe Jin $^{\mathrm{a}}$, Yuxiao Chen ${ }^{\mathrm{a}, *}$, Quanwei Fu ${ }^{\mathrm{b}}$ and Qingxing $\mathrm{Qu}^{\mathrm{a}}$ \\ ${ }^{a}$ School of Business Administration, Northeastern University, Shenyang, China \\ ${ }^{\mathrm{b}}$ Dongguan Kanghua Hospital, Dongguan, China
}

Received 23 March 2021

Accepted 30 March 2021

\begin{abstract}
.
BACKGROUND: With the spread of COVID-19 and the worsening global prevention and control situation, the risk of infection faced by health workers has been unprecedented. It is necessary to fully understand the occupational risks of health workers to protect them and reduce their risk of infection.

OBJECTIVE: This study aimed to obtain comprehensive and detailed information on occupational risk factors of infectious diseases for HWs in different dimensions and to propose control strategies for three risk dimensions to protect HWs who are at high risk of infection during the pandemic.

METHODS: A total number of 619 articles published from 2010 to 2021 were searched to conduct bibliometric analysis, which were retrieved in the Web of Science database with defined search terms. There were 26 articles met the criteria, and they were screened to identify occupational risk factors.

RESULTS: We conducted an analysis of cited institutions, co-citation network analysis of journals, and references from bibliometric analysis. Nine risk factors were extracted, and they were classified and sorted into three dimensions. Infection control strategies for each dimension were proposed.

CONCLUSIONS: The risk of infection faced by HWs is unprecedented. Medical institutions should pay more attention to the nine risk factors that we identified and use the three risk dimensions to carry out risk identification and infection control to reduce the infection risk of HWs and protect them better.
\end{abstract}

Keywords: Coronavirus 2, occupational safety, infection risk factors, infection control strategies, bibliometric analysis

\section{Introduction}

With the rapid spread of a new coronavirus around the world, as of March 23, 2021, the cumulative number of confirmed cases worldwide has

\footnotetext{
*Address for correspondence: Yuxiao Chen, School of Business Administration, Northeastern University, NO. 195, Chuangxin Road, Hunnan District, Shenyang, 110167, China. E-mail: yuxiao_chen1@163.com.
}

reached 124,287,980. The World Health Organization (WHO) named the virus 'severe acute respiratory syndrome coronavirus 2' (SARS-CoV-2), and the disease caused by infection with this virus is called 'coronavirus disease' (COVID-19) [1].

The large-scale pandemic of the SARS-CoV-2 virus has overwhelmed medical systems, and shortages of medical supplies, and poor infection control have put health workers (HWs) increasingly at risk 
of infection [2]. HWs are at the forefront of fighting the pandemic, and they are a high-risk group that need special protection [3]. Studies have shown that in Italy and Spain, 9\% and 26\% of HWs who were tested with the polymerase chain reaction method had COVID-19, respectively [4, 5]. The infection rate of COVID-19 in HWs is high, ranging from 3\% to $17 \%$ [3]. On January 13, 2021, the WHO stated that given the spread of COVID-19, especially as more infectious mutant viruses spread in the northern hemisphere, the second year of the new coronavirus pandemic may be more difficult than the first year [6]. At the same time, with the mutation of the virus, the risk of infection has further increased. Studies have confirmed that the fatal risk of the new coronavirus variant strain found in the United Kingdom is 35\% higher than that of the original strain, which poses a further challenge to the current global pandemic prevention and control situation [7]. Therefore, for HWs at high risk of infection, identifying and assessing their own risk factors is particularly important to protect themselves.

However, the research on the risk factors of infectious diseases among HWs is thinly spread and not comprehensive and systematic. In this study, we aimed to use various methods to obtain comprehensive and detailed information on occupational risk factors of infectious diseases for HWs in different dimensions, and to propose control strategies for these risk dimensions to protect HWs who are at high risk of infection during the pandemic.

\section{Methods}

\subsection{Search strategy}

This study aimed to review, extract, and summarise the risk factors of infectious diseases for HWs. We selected the Web of Science Core Collection for the literature search, and used the "Topic" research for retrieving published reports, reviews, and primary observational studies (case-control, cross-sectional, and cohort). To gather as much additional information as possible, every retrieval item was exported with "Full records and cited references" in ".txt" format from Web of Science. The time span was limited to 2010 to 2021 . The keywords used for the initial data collection included "Covid-19", "SARSCoV-2", "infectious disease", "health care worker", "nurse", "infectious factor", and "risk factor".

\subsection{Selection criteria}

We used a three-stage selection process to filter the literature. In the first stage, duplicate and irrelevant items were identified and deleted, and the initial data obtained was used for subsequent bibliometric visualisation analysis. In the second stage, the titles and abstracts of the remaining articles were screened to exclude obviously irrelevant studies. In the third stage, the full texts were briefly browsed to further screen the literature. After further screening, the final articles for information extraction were obtained. Inclusion criteria were all reports, reviews, and primary observational studies describing occupational risk factors for infectious diseases among HWs.

\subsection{Bibliometric analysis}

Bibliometrics uses mathematical and statistical methods to quantitatively analyse published articles. Its history can be traced back to the beginning of the 20th century. Its importance in research evaluation is increasing, and it has become a widely used method for analysing academic exchanges and evaluating research results [8]. It compares the citation influence of researchers, research groups and institutions at different times and in various disciplines. Since these two factors are not related to the quality of publications, these academic studies can be quantitatively evaluated [9].

Many software packages have been developed for bibliometric analysis, such as CiteSpace, HistCite, BibExcel, and CitNetExplorer. It is convenient to use CiteSpace to derive a sequence of co-citation networks from a series of equal length time interval slices. These time registered networks are merged and visualised in a panoramic view in such a way that intellectually significant articles can be identified based on their visually salient features [10]. Therefore, in this study, we used CiteSpace (5.7.R3) for our bibliometric analysis.

\section{Results}

\subsection{Analysis of institutions}

Institute statistics can provide information about the location and organisation where the research was completed. We used CiteSpace to extract the author's institution and its location information and counted the frequency of each institution. 
Table 1

The top 15 contributing institutes

\begin{tabular}{llcc}
\hline Number & Institute & Location & No.of docs \\
\hline 1 & Huazhong University of Science and Technology & China & 15 \\
2 & Centers for Disease Control and Prevention & USA & 9 \\
3 & Columbia University in the City of New York & USA & 9 \\
4 & The University of Melbourne & Australia & 8 \\
5 & Harvard Medical School & USA & 8 \\
6 & National Institute for Occupational Safety and Health & USA & 8 \\
7 & Wuhan University & China & 8 \\
8 & The University of Cape Town & South Africa & 7 \\
9 & The University of Michigan & USA & 7 \\
10 & Johns Hopkins University & USA & 6 \\
11 & Fudan University & China & 6 \\
12 & University of Toronto & Canada & 5 \\
13 & The University of New South Wales & Australia & 5 \\
14 & King's College London & UK & 5 \\
15 & Case Western Reserve University & USA & 4 \\
\hline
\end{tabular}

Table 2

The top 15 contributing Co-citation journals

\begin{tabular}{llc}
\hline Number & Journal & No.of docs \\
\hline 1 & Lancet & 221 \\
2 & New England Journal Of Medicine & 174 \\
3 & American Journal Of Infection Control & 154 \\
4 & Journal Of Hospital Infection & 149 \\
5 & Infection Control And Hospital Epidemiology & 146 \\
6 & Jama-journal Of The American Medical Association & 142 \\
7 & Plos One & 110 \\
8 & Clinical Infectious Diseases & 98 \\
9 & Annals Of Internal Medicine & 97 \\
10 & Emerging Infectious Diseases & 93 \\
11 & Lancet Infectious Diseases & 70 \\
12 & American Journal Of Industrial Medicine & 70 \\
13 & British Medical Journal & 63 \\
14 & International Journal Of Environmental Research And Public Health & 61 \\
15 & Bmc Public Health & 60 \\
\hline
\end{tabular}

Table 1 lists the top 15 contributing institutions. Huazhong University of Science and Technology in China ranks the best in this regard, with a total of 15 occurrences in the 619 studies included. In terms of geographic location, the United States has the strongest overall research strength in this area, with seven institutions, such as Columbia University in the City of New York and Harvard Medical School appearing in Table 1. In addition, the institutions listed in the table include not only world-class universities, but also national medical organizations, such as the Centers for Disease Control and Prevention. From this point of view, the research on infectious diseases and HWs is relatively widespread in terms of geographic location and institutional type.

\subsection{Analysis of co-citation journals}

An analysis of co-citation journals can help us understand the most cited journals and the research fields covered by the literature. Based on CiteSpace, we derived the co-citation information of the source journals of 15,853 references out of the 619 articles collected.

Table 2 lists the top 15 co-citation journals and frequency statistics. It shows that in the co-citation network formed by the 15,853 research studies, these journals have been cited the most times at the same time and have the greatest influence in this research field. Among them, Lancet has been co-cited the most, up to 221 times, and New England Journal of Medicine has been co-cited 174 times, which 
illustrates the important position of these journals in the medical field. In addition, most of the co-cited journals are journals in the fields of medicine, infection, or diseases in medicine or biology, indicating that the extraction of occupational risk factors for medical personnel is closely related to medicine and biology.

\subsection{Analysis of co-citation references}

In the quantitative research of bibliometrics, cocitation research is one of the most commonly used research methods, especially the References Cocitation Analysis [11, 12]. To further show the risk factors of infectious diseases for HWs, we used CiteSpace to conduct an article co-citation network analysis on the references cited in the search data set. We imported the 15,853 references from the 619 articles into CiteSpace. The nodes of the network were selected under the criteria that the top $10 \%$ of the most cited or occurred items were kept in each slice with the maximum number of selected items not more than 100 per slice.

There are a total of 544 nodes and 1040 edges in the citation network. Subsequently, we performed a cluster analysis on the resulting network. CiteSpace uses an internal spectral clustering algorithm to identify clusters, which is based on the eigenvectors of the Laplacian matrix derived from the original network. By integrating network visualisation, spectrum clustering, automatic clustering and text summarisation, the task of analysis and visualisation is simplified [13]. We used the CiteSpace clustering and cluster definition algorithm to obtain 117 clustering results, retaining the 11 main clusters, and obtaining the clustering results and the detailed information of each cluster label.
Figure 1 shows the clustering results of the cocitation network; the distribution of each cluster is relatively scattered. Among them, the research coverage about HWs is the widest, and the research is relatively scattered. The research on hand hygiene is relatively concentrated and has a large time span. Personal protective equipment (PPE) and hospital staff intersect the most with other clusters. To further understand the specific information of each cluster, we exported the detailed information results of the clusters.

Table 3 lists the specific information of each cluster label, sorted according to the number of members in the cluster from large to small, namely hand hygiene compliance, hospital staff, personal protective equipment, COVID-19 pneumonia, rescue strategy, hand hygiene, SARS-CoV-2 infection, Ebola virus disease,

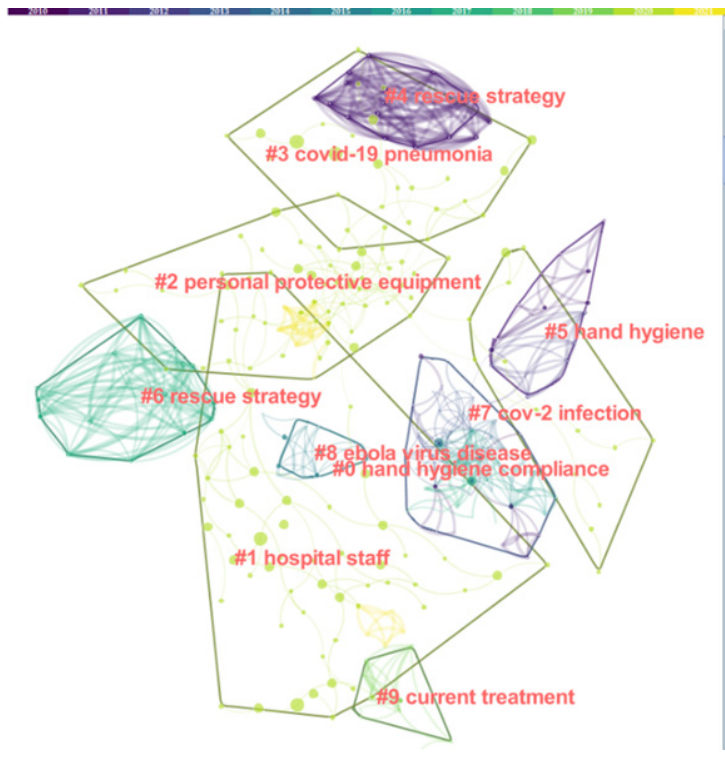

Fig. 1. Co-citation network cluster view.

Table 3

Specific information on the 11 major clusters

\begin{tabular}{llccc}
\hline Cluster ID & Cluster label & Number & Silhouette & Avg. year of docs \\
\hline$\# 0$ & Hand hygiene compliance & 59 & 0.963 & 2009 \\
$\# 1$ & Hospital staff & 57 & 0.976 & 2019 \\
$\# 2$ & Personal protective equipment & 57 & 0.894 & 2019 \\
$\# 3$ & COVID-19 pneumonia & 24 & 1.000 & 2019 \\
$\# 4$ & Rescue strategy & 17 & 1.000 & 2006 \\
$\# 5$ & Hand hygiene & 17 & 0.979 & 2007 \\
$\# 6$ & Rescue strategy & 15 & 1.000 & 2012 \\
$\# 7$ & Cov-2 infection & 14 & 1.000 & 2020 \\
$\# 8$ & Ebola virus & 13 & 0.896 & 2013 \\
$\# 9$ & Current treatment & 12 & 1.000 & 2013 \\
$\# 10$ & Isolation facilities & 10 & 0.996 & 2010 \\
\hline
\end{tabular}




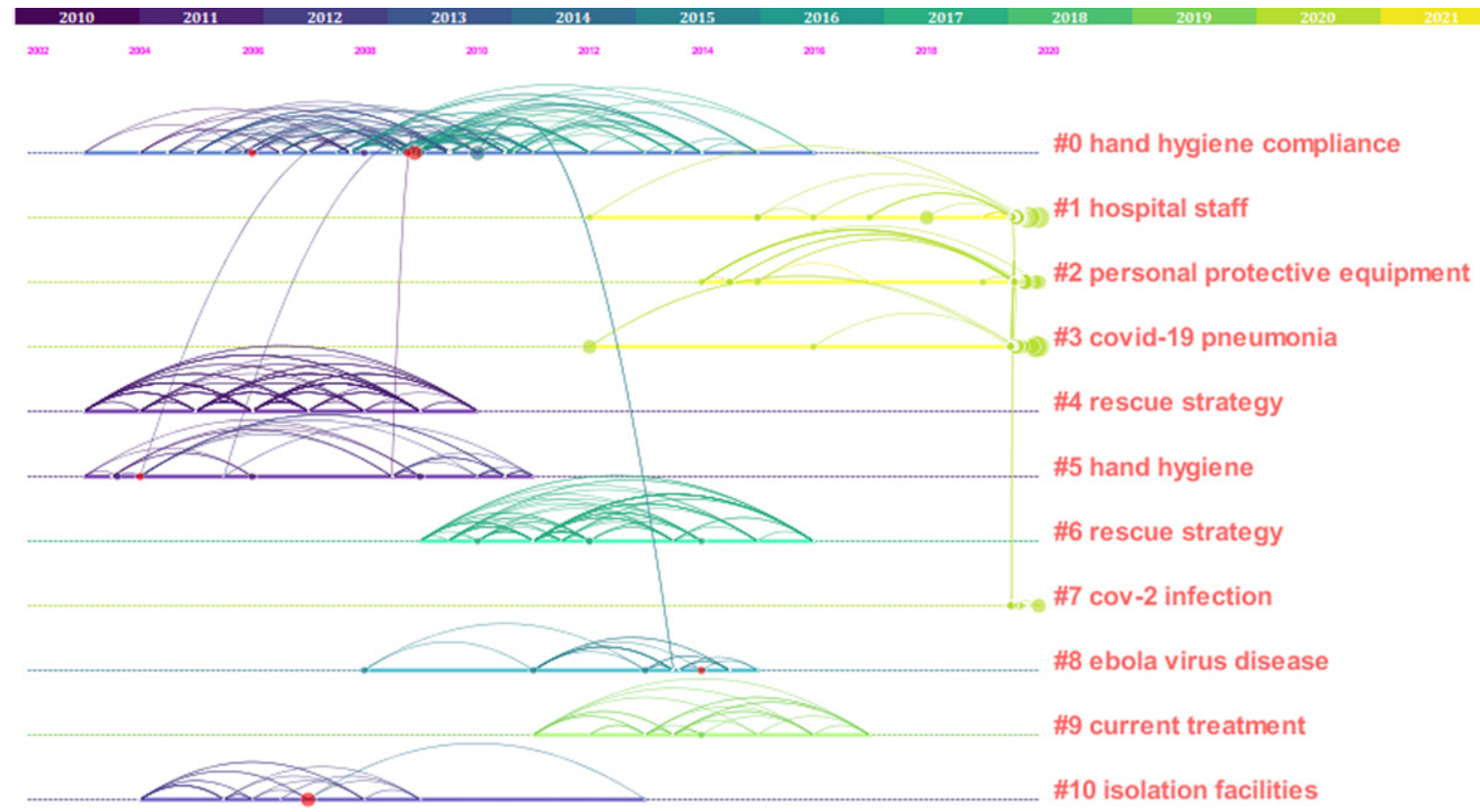

Fig. 2. Co-citation network timeline view.

current treatment, and isolation facilities. Considering that the smaller clusters are not representative, to avoid redundancy and overlap of the visual graphics, we filtered the clusters with fewer than 10 members among the 117 clusters. In each cluster, the indicator value "Silhouette", which measures the clustering result, is close to 1 , which means that each cluster has consistency within the other and that the results are convincing. In addition, Table 3 also shows the average publication year of the references contained in each cluster. There are more article clusters concentrated in 2019-2020.

To understand the time course of the research on risk factors of infectious diseases for HWs more intuitively and clearly, we derived a timeline view of the clusters from the calculation results of CiteSpace.

Based on Fig. 1 and Fig. 2, it can be concluded that the concerns about hand hygiene (\#0 hand hygiene compliance and \#5 hand hygiene) originated very early, judging by its citation in 2004. In addition, it involves the most research and is the largest cluster. Maintaining hand hygiene is considered to be the most important factor in preventing HWs from being infected. The transmission of infectious diseases from patients to HWs is usually because their hands are contaminated by contact with the virus [14].

Research on PPE (\#2 personal protective equipment) also became intensive after 2014. The infection of HWs with SARS-CoV-2 is probably caused, inter alia, by a lack of PPE or its incorrect use [15]. Having sufficient PPE and the correct use of PPE can effectively reduce HWs' risk of being infected with SARS-CoV-2 [16, 17].

Research on isolation facilities (\#10 isolation facilities) indicates that this is also an important risk factor. It began to receive widespread attention after SARS in 2003. Inadequate isolation facilities will increase the risk of HWs contracting infectious diseases. Placement of infectious patients in isolation facilities can effectively prevent HWs from contracting the virus [18].

In addition, the cluster (\#1 hospital staff) for HWs also has a high research prevalence. As the main force in the fight against COVID-19, HWs play an important role in the prevention and treatment of infectious diseases. Since HWs are in close contact with infected patients at work, if they cannot be fully protected, it will make them more susceptible to infectious viruses, which can contribute to paralysis of medical systems [3]. In addition, through the clustering results, it was be found that the main types of viruses infecting HWs are viruses such as SARSCoV-2, Ebola, and Middle East respiratory syndrome coronavirus (MERS-CoV).

On this basis, we also derived the 10 references with the strongest citation bursts through CiteSpace, as shown in Fig. 3. Co-citation references analyses the frequency of articles being cited by other articles 


\section{Top 10 References with the Strongest Citation Bursts}

References

Erasmus V, 2010, INFECT CONT HOSP EP, V31, P283, DOI

Allegranzi B, 2009, J HOSP INFECT, V73, P305, DOI

Pittet D, 2004, ANN INTERN MED, V141, P1, DOI

Pittet D, 2009, INFECT CONT HOSP EP, V30, P611, DOI

Siegel JD, 2007, AM J INFECT CONTROL, V35, P0, DOI

** WorldHealthOrganization, 2009, WHO GUID HAND HYG HL, VO, P0 2009

Allegranzi B, 2011, LANCET, V377, P228, DOI

Sax H, 2009, AM J INFECT CONTROL, V37, P827, DOI

Fischer WA, 2014, ANN INTERN MED, V161, P753, DOI

Feola G, 2010, INT J OCCUP ENV HEAL, V16, P11, DOI
2010

2009

2004

2009

2007

2011

2009

2014

2010

Year Strength Begin Ind

$2010-2021$

6.9320112016

4.5320112017

4.1220112012

3.4420112016

3.5820122014

5.4120132017

4.1920142017

4.6820152017

$\begin{array}{lll}3.32015 & 2017\end{array}$

2.7520152017

Fig. 3. Top 10 references with the strongest citation bursts.

at the same time, which helps to determine which articles have a significant impact in the research field and finds the key or core articles in the research field.

From Fig. 3, we can get the top ten articles cited in the research and the time period when they were frequently cited. This information can reflect the hotspots in this research field to a certain extent. In addition, the high-frequency citations of these top 10 references are also closely related to the formation of clusters in CiteSpace, and each cluster has a corresponding relationship with each strongest citation burst.

\subsection{Study findings}

Our initial keyword search obtained 628 articles that met the search criteria. After 9 articles with duplicate entries were eliminated through the first screening stage, 619 articles were obtained for bibliometric analysis. Then, the title of each article was preliminarily screened, and the articles related to infectious diseases and HWs were selected. A total of 66 articles met the requirements. The abstracts and full text of these articles were briefly browsed, and 24 articles that were not related to the risk factors of infectious diseases among HWs were excluded. After reading the remaining 42 articles, we excluded 16 articles that did not involve the study of occupational risk factors of HWs, and finally identified 26 articles for the extraction of risk factors.

We carefully read the full texts of the 26 articles used for information extraction and extracted relevant information from each article to obtain Table 4.
It includes 10 reviews [19-28], one case control study [29], six retrospective cohort studies [3, 14, 30-33], two cross-sectional studies [34, 35], two observational cohort studies [4, 36], two prospective cohort studies [16, 37], two reports [38, 39], and one interview [40]. One article was published in 2013, two articles were published in 2019, and 23 articles were published in 2020. The types of viruses and diseases included in the studies are COVID-19, MERS-CoV, SARS, latent tuberculosis, bloodborne illnesses, and respiratory infections.

The information extracted in Table 4 specifically includes first author, country, publication year, title, study design, sample size, population, disease profile, and risk factor. To ensure the consistency, only one reviewer extracted the risk factors in the articles. The reviewer first carefully read the 26 articles and then summarised the risk factors in each article, classified and organized them, and created related narratives.

According to the extraction results, the occupational risk factors for HWs to contract the virus can be divided into nine categories. They are exposure to infected patients and the virus, lack of PPE, suboptimal hand hygiene, lack of infection control training, work overload, mental stress, cross-infection, unsafe disposal of medical waste, and inadequate disinfection.

The lack of PPE and exposure to infected patients and the virus are the most important risk factors for HWs. A total of 19 risk factors extracted from the research include these two factors. According to the results of the studies, both surgical and N95 masks can effectively prevent HWs from contracting 
Table 4

Characteristics of 26 included articles

\begin{tabular}{|c|c|c|c|c|c|c|c|}
\hline $\begin{array}{l}\text { First author, } \\
\text { year }\end{array}$ & Country & Title & Study design & Sample size & Population & Disease type & Risk factors \\
\hline $\begin{array}{l}\text { Mhango } \\
\text { et al., } 2020\end{array}$ & South Africa & $\begin{array}{l}\text { COVID-19 Risk Factors Among Health } \\
\text { Workers: A Rapid Review }\end{array}$ & Rapid review & Not specified & Health workers & COVID-19 & $\begin{array}{l}\text { Exposure to infected patients and the } \\
\text { virus, lack of personal protective } \\
\text { equipment, and work overload }\end{array}$ \\
\hline $\begin{array}{l}\text { Zhao et al., } \\
2020\end{array}$ & China & $\begin{array}{l}\text { Radiology department strategies to protect } \\
\text { radiologic technologists against } \\
\text { COVID19: Experience from Wuhan }\end{array}$ & Review & Not specified & $\begin{array}{l}\text { Radiologic } \\
\text { technologists }\end{array}$ & COVID-19 & $\begin{array}{l}\text { Lack of personal protective equipment, } \\
\text { cross-infection, work over-load, unsafe } \\
\text { disposal of medical waste, and } \\
\text { inadequate disinfection }\end{array}$ \\
\hline $\begin{array}{l}\text { Tang et al., } \\
2020\end{array}$ & China & $\begin{array}{l}\text { Avoiding health worker infection and } \\
\text { containing the coronavirus disease } 2019 \\
\text { pandemic: Perspectives from the } \\
\text { frontline in Wuhan }\end{array}$ & Review & Not specified & Health workers & COVID-19 & $\begin{array}{l}\text { Lack of personal protective equipment, } \\
\text { cross-infection, work over-load, } \\
\text { inadequate disinfection, unsafe disposal } \\
\text { of medical waste, and lack of awareness } \\
\text { and an inaccessibility of disease } \\
\text { information }\end{array}$ \\
\hline $\begin{array}{l}\text { Patil et al., } \\
2020\end{array}$ & Saudi Arabia & $\begin{array}{l}\text { Dental care and personal protective } \\
\text { measures for dentists and non-dental } \\
\text { health care workers }\end{array}$ & Review & Not specified & $\begin{array}{l}\text { Dental health } \\
\text { workers }\end{array}$ & COVID-19 & $\begin{array}{l}\text { Exposure to infected patients and the } \\
\text { virus, lack of personal protective } \\
\text { equipment, hand hygiene, and unsafe } \\
\text { disposal of medical waste }\end{array}$ \\
\hline $\begin{array}{l}\text { Macintyre } \\
\text { et al., } 2013\end{array}$ & Australia & $\begin{array}{l}\text { Quantifying the risk of respiratory } \\
\text { infection in healthcare workers } \\
\text { performing high-risk procedures }\end{array}$ & Case control & 481 & Health workers & $\begin{array}{l}\text { Respiratory } \\
\text { infection }\end{array}$ & $\begin{array}{l}\text { Exposure to infected patients and the } \\
\text { virus, lack of personal protective } \\
\text { equipment, hand hygiene, and } \\
\text { cross-infection }\end{array}$ \\
\hline $\begin{array}{l}\text { Cournoyer } \\
\text { et al., } 2020\end{array}$ & Australia & $\begin{array}{l}\text { Oxygen Therapy and Risk of Infection for } \\
\text { Health Care Workers Caring for Patients } \\
\text { With Viral Severe Acute Respiratory } \\
\text { Infection: A Systematic Review and } \\
\text { Meta-analysis }\end{array}$ & $\begin{array}{l}\text { Systematic } \\
\text { review }\end{array}$ & Not specified & Health workers & $\begin{array}{l}\text { Respiratory } \\
\text { infection }\end{array}$ & $\begin{array}{l}\text { Exposure to infected patients and the } \\
\text { virus, hand hygiene, and lack of } \\
\text { infection control training }\end{array}$ \\
\hline $\begin{array}{l}\text { Alajmi et al., } \\
2020\end{array}$ & Qatar & $\begin{array}{l}\text { COVID-19 infection among healthcare } \\
\text { workers in a national healthcare system: } \\
\text { The Qatar experience }\end{array}$ & $\begin{array}{l}\text { Retrospective } \\
\text { cohort }\end{array}$ & 393 & Health workers & COVID-19 & $\begin{array}{l}\text { Exposure to infected patients and the } \\
\text { virus, and lack of personal protective } \\
\text { equipment }\end{array}$ \\
\hline $\begin{array}{l}\text { Mossburg } \\
\text { et al., } 2019\end{array}$ & Africa & $\begin{array}{l}\text { Occupational Hazards among Healthcare } \\
\text { Workers in Africa: A Systematic Review }\end{array}$ & $\begin{array}{l}\text { Systematic } \\
\text { review }\end{array}$ & Not specified & Health workers & $\begin{array}{l}\text { Bloodborne } \\
\text { disease }\end{array}$ & $\begin{array}{l}\text { Exposure to infected patients and the } \\
\text { virus, lack of personal protective } \\
\text { equipment, unsafe disposal of medical } \\
\text { waste, and lack of infection control } \\
\text { training }\end{array}$ \\
\hline
\end{tabular}


Table 4

(Continued)

\begin{tabular}{|c|c|c|c|c|c|c|c|}
\hline $\begin{array}{l}\text { First author, } \\
\text { year }\end{array}$ & Country & Title & Study design & Sample size & Population & Disease type & Risk factors \\
\hline $\begin{array}{l}\text { Iversen et al., } \\
2020\end{array}$ & Denmark & $\begin{array}{l}\text { Risk of COVID-19 in health-care workers } \\
\text { in Denmark: an observational cohort } \\
\text { study }\end{array}$ & $\begin{array}{l}\text { Observational } \\
\text { cohort }\end{array}$ & 29884 & $\begin{array}{l}\text { Doctors, nurses, } \\
\text { assistant, and } \\
\text { medical } \\
\text { students }\end{array}$ & COVID-19 & $\begin{array}{l}\text { Exposure to infected patients and the } \\
\text { virus, and lack of personal protective } \\
\text { equipment }\end{array}$ \\
\hline $\begin{array}{l}\text { Zhang et al., } \\
2020\end{array}$ & China & $\begin{array}{l}\text { Factors associated with asymptomatic } \\
\text { infection in health-care workers with } \\
\text { severe acute respiratory syndrome } \\
\text { coronavirus } 2 \text { infection in Wuhan, } \\
\text { China: a multicentre retrospective } \\
\text { cohort study }\end{array}$ & $\begin{array}{l}\text { Retrospective } \\
\text { cohort }\end{array}$ & 424 & Health workers & COVID-19 & $\begin{array}{l}\text { Exposure to infected patients and the } \\
\text { virus, lack of personal protective } \\
\text { equipment, and hand hygiene }\end{array}$ \\
\hline $\begin{array}{l}\text { Vimercati } \\
\text { et al., } 2020\end{array}$ & Italy & $\begin{array}{l}\text { COVID-19 hospital outbreaks: Protecting } \\
\text { healthcare workers to protect frail } \\
\text { patients. An Italian observational cohort } \\
\text { study }\end{array}$ & $\begin{array}{l}\text { Observational } \\
\text { cohort }\end{array}$ & 5750 & $\begin{array}{l}\text { Doctors, nurses, } \\
\text { social health } \\
\text { assistants }\end{array}$ & COVID-19 & $\begin{array}{l}\text { Exposure to infected patients and the } \\
\text { virus, lack of personal protective } \\
\text { equipment, and mental stress }\end{array}$ \\
\hline $\begin{array}{l}\text { Nishimura } \\
\text { et al., } 2018\end{array}$ & Japan & $\begin{array}{l}\text { Risk of tuberculosis infection among } \\
\text { health care workers and nursing students } \\
\text { in Japan }\end{array}$ & $\begin{array}{l}\text { Prospective } \\
\text { cohort }\end{array}$ & 626 & $\begin{array}{l}\text { Health workers } \\
\text { and nursing } \\
\text { students }\end{array}$ & Tuberculosis & Exposure to infected patients and the virus \\
\hline $\begin{array}{l}\text { Chen et al., } \\
2018\end{array}$ & China & $\begin{array}{l}\text { Prevalence and determinants of latent } \\
\text { tuberculosis infection among frontline } \\
\text { tuberculosis healthcare workers in } \\
\text { southeastern China: A multilevel } \\
\text { analysis by individuals and health } \\
\text { facilities }\end{array}$ & $\begin{array}{l}\text { Cross- } \\
\text { sectional }\end{array}$ & 487 & Health workers & $\begin{array}{l}\text { Latent } \\
\text { tuberculosis }\end{array}$ & $\begin{array}{l}\text { Exposure to infected patients and the } \\
\text { virus, lack of personal protective } \\
\text { equipment, work overload, inadequate } \\
\text { disinfection, and lack of infection } \\
\text { control training }\end{array}$ \\
\hline $\begin{array}{l}\text { Wang et al., } \\
2020\end{array}$ & China & $\begin{array}{l}\text { Risk factors of SARS-CoV-2 infection in } \\
\text { healthcare workers: a retrospective } \\
\text { study of a nosocomial outbreak }\end{array}$ & $\begin{array}{l}\text { Retrospective } \\
\text { cohort }\end{array}$ & 118 & Health workers & COVID-19 & $\begin{array}{l}\text { Exposure to infected patients and the } \\
\text { virus, lack of personal protective } \\
\text { equipment, work overload, and mental } \\
\text { stress }\end{array}$ \\
\hline $\begin{array}{l}\text { Elkholy et al., } \\
2019\end{array}$ & Egypt & $\begin{array}{l}\text { MERS-CoV infection among healthcare } \\
\text { workers and risk factors for death: } \\
\text { Retrospective analysis of all } \\
\text { laboratory-confirmed cases reported to } \\
\text { WHO from } 2012 \text { to } 2 \text { June } 2018\end{array}$ & $\begin{array}{l}\text { Retrospective } \\
\text { cohort }\end{array}$ & 2223 & Health workers & MERS & $\begin{array}{l}\text { Exposure to infected patients and the } \\
\text { virus, lack of personal protective } \\
\text { equipment, and lack of infection control } \\
\text { training }\end{array}$ \\
\hline $\begin{array}{l}\text { Suzuki et al., } \\
2020\end{array}$ & Japan & $\begin{array}{l}\text { Effectiveness of personal protective } \\
\text { equipment in preventing severe acute } \\
\text { respiratory syndrome coronavirus } 2 \\
\text { infection among healthcare workers }\end{array}$ & $\begin{array}{l}\text { Prospective } \\
\text { cohort }\end{array}$ & 49 & Health workers & COVID-19 & $\begin{array}{l}\text { Exposure to infected patients and the } \\
\text { virus, lack of personal protective } \\
\text { equipment, and hand hygiene }\end{array}$ \\
\hline
\end{tabular}




\begin{tabular}{|c|c|c|c|c|c|c|c|}
\hline $\begin{array}{l}\text { Ran et al., } \\
2020\end{array}$ & China & $\begin{array}{l}\text { Risk Factors of Healthcare Workers With } \\
\text { Coronavirus Disease 2019: A } \\
\text { Retrospective Cohort Study in a } \\
\text { Designated Hospital of Wuhan in China }\end{array}$ & $\begin{array}{l}\text { Retrospective } \\
\text { cohort }\end{array}$ & 72 & Health workers & COVID-19 & $\begin{array}{l}\text { Exposure to infected patients and the } \\
\text { virus, hand hygiene, and work overload }\end{array}$ \\
\hline $\begin{array}{l}\text { Piccoli et al., } \\
2020\end{array}$ & Switzerland & $\begin{array}{l}\text { Risk assessment and seroprevalence of } \\
\text { SARS-CoV-2 infection in healthcare } \\
\text { workers of COVID-19 and } \\
\text { non-COVID-19 hospitals in Southern } \\
\text { Switzerland }\end{array}$ & $\begin{array}{l}\text { Cross- } \\
\text { sectional }\end{array}$ & 4726 & Health workers & COVID-19 & $\begin{array}{l}\text { Exposure to infected patients and the } \\
\text { virus, lack of personal protective } \\
\text { equipment, and hand hygiene }\end{array}$ \\
\hline $\begin{array}{l}\text { Maltezou } \\
\text { et al., } 2020\end{array}$ & Greece & $\begin{array}{l}\text { Hospital factors associated with } \\
\text { SARS-CoV-2 infection among } \\
\text { healthcare personnel in Greece }\end{array}$ & Short report & Not specified & Health workers & COVID-19 & $\begin{array}{l}\text { Exposure to infected patients and the } \\
\text { virus, lack of personal protective } \\
\text { equipment, hand hygiene, inadequate } \\
\text { disinfection, and lack of infection } \\
\text { control training }\end{array}$ \\
\hline $\begin{array}{l}\text { Fryk et al., } \\
2020\end{array}$ & Australia & $\begin{array}{l}\text { Knowledge, attitudes and practices of } \\
\text { healthcare workers within an Australian } \\
\text { tertiary hospital to managing } \\
\text { high-consequence infectious diseases }\end{array}$ & $\begin{array}{l}\text { Structured } \\
\text { interviews }\end{array}$ & 45 & $\begin{array}{l}\text { Medical officers } \\
\text { and nurses }\end{array}$ & COVID-19 & $\begin{array}{l}\text { Lack of infection control training, and } \\
\text { mental stress }\end{array}$ \\
\hline $\begin{array}{l}\text { Xiao et al., } \\
2020\end{array}$ & China & $\begin{array}{l}\text { SARS, MERS and COVID-19 among } \\
\text { healthcare workers: A narrative review }\end{array}$ & $\begin{array}{l}\text { Narrative } \\
\text { review }\end{array}$ & Not specified & Health workers & SARS & $\begin{array}{l}\text { Exposure to infected patients and the } \\
\text { virus, lack of personal protective } \\
\text { equipment, hand hygiene, } \\
\text { cross-infection, mental stress, and lack } \\
\text { of infection control training }\end{array}$ \\
\hline $\begin{array}{l}\text { Viswanath } \\
\text { et al., } 2020\end{array}$ & Singapore & $\begin{array}{l}\text { Working through the COVID-19 outbreak: } \\
\text { Rapid review and recommendations for } \\
\text { MSK and allied heath personnel }\end{array}$ & Rapid review & Not specified & $\begin{array}{l}\text { Musculoskeletal } \\
\text { (MSK) health } \\
\text { workers }\end{array}$ & MERS & $\begin{array}{l}\text { Exposure to infected patients and the } \\
\text { virus, lack of personal protective } \\
\text { equipment, and mental stress }\end{array}$ \\
\hline $\begin{array}{l}\text { Bai et al., } \\
2020\end{array}$ & China & $\begin{array}{l}\text { SARS-CoV-2 infection in health care } \\
\text { workers: a retrospective analysis and } \\
\text { model study }\end{array}$ & $\begin{array}{l}\text { Retrospective } \\
\text { cohort }\end{array}$ & 171 & Health workers & COVID-19 & $\begin{array}{l}\text { Exposure to infected patients and the } \\
\text { virus, lack of personal protective } \\
\text { equipment, and mental stress }\end{array}$ \\
\hline Yu et al., 2020 & China & $\begin{array}{l}\text { Infection Control against COVID-19 in } \\
\text { Departments of Radiology }\end{array}$ & Review & Not specified & $\begin{array}{l}\text { Health workers in } \\
\text { departments of } \\
\text { radiology }\end{array}$ & COVID-19 & $\begin{array}{l}\text { Exposure to infected patients and the } \\
\text { virus, cross-infection, and lack of } \\
\text { infection control training }\end{array}$ \\
\hline $\begin{array}{l}\text { Schwartz } \\
\text { et al., } 2020\end{array}$ & $\begin{array}{r}\text { Taiwan, } \\
\text { China }\end{array}$ & $\begin{array}{l}\text { Protecting Healthcare Workers During the } \\
\text { Coronavirus Disease } 2019 \text { (COVID-19) } \\
\text { Outbreak: Lessons From Taiwan's } \\
\text { Severe Acute Respiratory Syndrome } \\
\text { Response }\end{array}$ & Brief report & Not specified & Health workers & COVID-19 & $\begin{array}{l}\text { Exposure to infected patients and the } \\
\text { virus, lack of personal protective } \\
\text { equipment, hand hygiene, mental stress, } \\
\text { and inadequate disinfection }\end{array}$ \\
\hline $\begin{array}{l}\text { Ing et al., } \\
2020\end{array}$ & Canada & $\begin{array}{l}\text { Physician deaths from corona virus } \\
\text { (COVID-19) disease }\end{array}$ & Review & 278 & Health workers & COVID-19 & $\begin{array}{l}\text { Exposure to infected patients and the } \\
\text { virus, lack of personal protective } \\
\text { equipment, and mental stress }\end{array}$ \\
\hline
\end{tabular}


COVID-19, MERS-CoV, SARS, and other respiratory infectious diseases, and the use of N95 can effectively reduce HWs' risk of being infected with SARS-CoV-2 [25, 41, 42]. In Denmark, HWs lacking PPE will have an increased risk of contracting the virus [4]. Among HWs infected by the virus in China, those who use N95 protective masks are mostly infected mildly and asymptomatically [30]. An Italian study showed, among the $10 \mathrm{HW}$ patients with severe COVID-19, nine were infected due to contact with infected colleagues without PPE [36].

Suboptimal hand hygiene is also one of the main risk factors. Hand hygiene is considered to be an effective way to prevent respiratory infections such as COVID-19, MERS-CoV, and SARS [25, 43, 44]. Maintaining hand hygiene is a well-known key measure to reduce cross-infection in medical facilities. Saudi Arabia physicians have suggested that after contact with contaminated medical equipment, the surrounding environment, and biological tissues, hands should be thoroughly cleaned with alcohol and soap [22].

Lack of training or poor knowledge is also one of the reasons why HWs contract the virus. The survey results of two studies in Africa showed that among HWs, $21 \%-32 \%$ of the respondents indicated that they lacked training or had poor knowledge about the latest measures to prevent infectious diseases [45, 46]. This will increase their risk of contracting infectious diseases. In the early stage of COVID-19 in China, the main reason for the large number of infections among HWs was lack of information about the virus and lack of training on the latest infection control methods [21]. Regular infection control training helps to reduce the risk of infection, and assists HWs to have the latest knowledge about virus control and prevention methods, so as to protect them from virus infection [34, 47].

Work overload and mental stress are also considered risk factors for HWs to contract infectious diseases. Research showed that HWs in China generally work longer hours, with an average working time of more than 54 hours per week. As the daily working hours of HWs increase, their likelihood of contracting COVID-19 will increase [14]. Work overload means that HWs lack the necessary rest, and at the same time exposes them to patients and viruses for a longer time, which increases the risk of infection [19, 39, 48]. In addition, longer working hours and a larger workload lead to mental stress in HWs. They are under greater psychological pressure when caring for infected persons. A study in China analysed the mental health status of 1,257 HWs caring for COVID-19 patients and found that $50.4 \%, 44.6 \%, 34.0 \%$, and $71.5 \%$ of them had depression, anxiety, insomnia, and distress, respectively [49]. During the COVID-19 pandemic, HWs in Taiwan devote more time to coping with a high work load under conditions of tremendous psychological pressure and with insufficient resources, which will further increase their anxiety[39]. In Taiwan, HWs' anxiety was further impacted by growing stigmatisation and loss of trust by their own communities during SARS [50].

In addition, the risk factors for HWs to contract infectious diseases also include cross-infection, unsafe disposal of medical waste, and inadequate disinfection. HWs are on the front line of fighting the virus, and they are prone to cross-infection of patients-to-HWs and HWs-to-HWs in their working environment, especially when the virus information is not clear at the initial stage $[31,51,52]$. According to Chinese radiologic technologists, HWs in radiology departments are at greater risk of cross-infection during COVID-19, and how to avoid cross-infection in this environment is particularly important [20]. The treatment of medical waste should be implemented in accordance with "Medical Waste Management and Regulations". The waste of patients with COVID-19 should be regarded as infectious medical waste, and special sealed packaging should be used to properly dispose of it to prevent cross-infection [20]. A study in Taiwan showed routine disinfection of the daily working environment of HWs and the transitional environment in contact with patients can reduce the possibility of cross-infection for HWs [39].

\section{Discussion}

The global impact of the COVID-19 pandemic has further deepened. As the front-line personnel in the fight against the pandemic, HWs are more susceptible to infection in their working environment. However, most of the research on the infection of HWs focuses on the external process of infection, such as hand hygiene, PPE, and cross-infection. HWs' own risk factors such as work overload and mental stress are rarely researched. Regarding the research on the risk factors of HWs, there is a rapid review that extracted five risk factors for HWs from 11 articles, but the number of articles included, the types of diseases, and the number of risk factors were not detailed and comprehensive [19]. 
Table 5

Risk factor classification

\begin{tabular}{lll}
\hline Source of infection & Transmission route & Susceptible population (HWs) \\
\hline Exposure to infected patients and the virus & Lack of personal protective equipment & Lack of infection control training \\
Unsafe disposal of medical waste & Suboptimal hand hygiene & Work overload \\
Inadequate disinfection & Cross-infection & Mental stress \\
\hline
\end{tabular}

To conduct a more comprehensive and detailed analysis and classification of the occupational COVID-19 infection risk factors of HWs under the current new prevention and control situation, we first used bibliometrics to conduct a statistical analysis of published literature. This method has obvious advantages in quantitative analysis and objectivity, but it cannot consider all particularities or special features of the objects to be assessed [53]. To obtain a more comprehensive and detailed statistical analysis result, we further selected 26 articles that meet the standards for information extraction, and obtained a total of nine occupational risk factors for infectious diseases among HWs. In order to sort and classify the 9 risk factors from different levels, and propose risk control strategies for different levels, we can classify the 9 risk factors obtained according to the source of infection, the route of transmission, and HWs. The nine risk factors can be classified into three dimensions (Table 5), for which different risk control strategies can be proposed: the source of the infection, the transmission route, and the susceptible population (HWs in this case).

Table 5 lists the classification of risk factors in three dimensions, each of which contains three risk factors. Among them, infectious sources mainly refer to people or things that carry viruses, such as infected patients, and medical waste. We classified exposure to infected patients and the virus, unsafe disposal of medical waste, and inadequate disinfection as the risk factors as this category, which means the risk factors that may cause HWs to contract viruses. The route of transmission refers to the way in which HWs are infected, such as via their hands and their working environment such as wards and office areas. This dimension also includes the lack of PPE, suboptimal hand hygiene, and cross-infection. The susceptible population dimension refers to high-risk HWs themselves who are in direct or indirect contact with patients with infectious diseases. We classified lack of infection control training, work overload, and mental stress into this dimension, which indicates that the HWs own conditions may lead to risk factors for infection by the virus.
The spread of infectious diseases in an epidemic way must meet three conditions, namely, source of infection, route of transmission, and susceptible population, which are collectively referred to as the three links of the epidemic process [44]. If one of these links are missing, new infections cannot occur, and it is therefore impossible for the disease to spread through the population. Using the three dimensions of infectious diseases to classify infection risks is conducive to proposing control methods to reduce these risks for HWs.

To control the source of infection, the possibility of HWs being exposed to these sources should first be reduced. Research in Denmark has shown that the risk of SARS-CoV-2 infection of HWs is closely related to exposure to the source of infection [4]. To reduce these risks, paperless and informationbased working methods should be promoted, such as establishing online virtual clinics and issuing electronic medical records, and prescriptions. Teaching of clinical or practical subjects would benefit from the use of virtual systems [54]. In addition, artificial intelligence technology can also be fully applied to serving HWs, which could not only reduce exposure but also reduce their workload [21]. All instruments or equipment and tissues used by patients with COVID-19 should be regarded as infectious medical waste. These should be disposed of in easy recognisable packaging and sealed in accordance with the provisions of "Medical Waste Management and Regulations" [22]. According to the risk assessment, appropriate disinfection standards should be established, and the transition area between the isolation area and the clean area should be fully and comprehensively disinfected every day, including air disinfection, surface wiping disinfection, and floor disinfection of different areas [20].

For the control of transmission routes, Chinese radiologic technologists have suggested that the approach of "three areas and two passages" can be applied [20]. It means setting up three areas, that is, a contaminated area, potentially contaminated area, and clean area, as well as two buffer rooms between the potentially contaminated area and the clean area to further ensure safety. In addition, there should be a 
distinction between patient passages and medical personnel passages to avoid cross-infection between the two groups. Further, HWs should use $75 \%$ ethanol to treat their hands every time they take care of patients or use equipment and keep their hands clean at all times [22]. Regarding PPE, research has shown that all personnel should wear masks [55], and HWs should implement different levels of personal protective measures according to the risk level of their respective regions [21]. To ensure the safety of HWs, governments and hospitals should make full efforts and coordinate to ensure the adequate reserves and supplies of PPE for them [21].

With regards to the dimension of HWs themselves, a Chinese study showed that designated professionals should be made infection managers, and all members of the department should be trained on the latest guidelines for diagnosis, treatment, and control specifications, which can effectively reduce the infection risk of staff members [20]. All HWs should receive online training before commencing work. Mutual help and supervision between HWs can help to reduce the incidence of infection [21]. Italian physicians have suggested that the establishment of community centres or home care systems for COVID-19 patients can not only reduce the workload of HWs, but also reduce the spread of the disease and the exposure of HWs [56]. In addition, hospitals should pay full attention to the mental health of HWs. They must pay attention to possible post-traumatic stress syndrome and occupational concerns of HWs, and should temporarily invite a psychologist or psychological counsellor to participate in the management of the hospital if necessary [25].

\section{Limitations and future research}

This study was a more comprehensive and systematic evaluation of the research on occupational risk factors of infectious diseases among HWs than previous evaluations, including multiple types of infectious diseases, multiple research methodologies, and different countries. In addition, we also classified the extracted risk factors according to three dimensions and proposed control strategies for each dimension. However, our research also has limitations. First, when using CiteSpace for cluster analysis, only the 10 clusters with the most members were retained in this article. Many of the smaller clusters were filtered out, so some important information may have been ignored, which could affect the risk factors in the clustering results. Second, as the current pandemic is further developing, the currently reported statistics on the infection information of HWs may be underestimated, so there may be the possibility that certain risk factors may have been ignored.

This study provides a systematic risk identification focus for HWs at high risk of infection, which is helpful for HWs to identify their own risk of infection. In addition, it also provides medical institutions with a systematic focus on protecting HWs from infection. Future research can build a quantitative model for evaluating the occupational risk factors of medical personnel in the medical service system based on the nine risk factors proposed in this paper to test the infection risk of HWs themselves, and take active measures against weak links.

\section{Conclusion}

This study used bibliometrics to analyse the 619 articles related to the risk factors of infectious diseases in HWs from 2010 to 2021 and used CiteSpace to analyse the cited institutions, co-cited journals, and co-citation networks of references from a macro perspective. We then conducted a microscopic analysis and extracted nine risk factors from 26 articles. We classified the risk factors into three dimensions and proposed corresponding infection control strategies for each dimension.

With the further spread of COVID-19 and the increasing seriousness of the disease prevention and control situation, the risk of infection faced by HWs is unprecedented. Medical institutions should pay more attention to the nine risk factors that we identified and use the three risk dimensions to carry out risk identification and infection control to reduce the infection risk of HWs and protect them better.

\section{Conflict of interest}

None to report.

\section{Funding}

This work was supported by the National Natural Science Foundation of China (Grant No. 71701039) and the Fundamental Research Funds for the Central Universities (Grant No. N2106007). 


\section{References}

[1] Huang C, Wang Y, Li X, Ren L, Zhao J, Hu Y, et al. Clinical features of patients infected with 2019 novel coronavirus in Wuhan, China. Lancet. 2020;395(10223):497-506.

[2] Wang X, Zhou Q, He Y, Liu L, Ma X, Wei X, et al. Nosocomial outbreak of 2019 novel coronavirus. Eur Respir J. 2020;

[3] Alajmi J, Jeremijenko AM, Abraham JC, Alishaq M, Concepcion EG, Butt AA, et al. COVID-19 infection among healthcare workers in a national healthcare system: The Qatar experience. Int J Infect Dis [Internet]. 2020;100: 386-9. Available from: https://doi.org/10.1016/j.ijid.2020 .09 .027

[4] Iversen K, Bundgaard H, Hasselbalch RB, Kristensen JH, Nielsen PB, Pries-Heje M, et al. Risk of COVID-19 in health-care workers in Denmark: an observational cohort study. Lancet Infect Dis. 2020;20(12):1401-8.

[5] Remuzzi A, Remuzzi G. COVID-19 and Italy: what next? Lancet [Internet]. 2020;395(10231):1225-8. Available from: http://dx.doi.org/10.1016/S0140-6736(20)30627-9

[6] Nancy L. Death risk higher from UK virus variant; vaccine in pregnancy may protect newborns [Internet]. 2021. Available from: https://www.reuters.com/article/idUSL1N2K E29Z

[7] TASS. The second year of the epidemic may be more severe than the previous year [Internet]. 2021. Available from: https://tass.ru/obschestvo/10454383

[8] Haustein S, Larivière V. The use of bibliometrics for assessing research: Possibilities, limitations and adverse effects. Incent Perform Gov Res Organ. 2015;121-39.

[9] Bornmann L, Marx W. Methods for the generation of normalized citation impact scores in bibliometrics: Which method best reflects the judgements of experts? J Informetr [Internet]. 2015;9(2):408-18. Available from: http://dx.doi. org/10.1016/j.joi.2015.01.006

[10] Chen C. Searching for intellectual turning points: Progressive knowledge domain visualization. Proc Natl Acad Sci U S A. 2004;101(SUPPL. 1):5303-10.

[11] Chen C. CiteSpace II: Detecting and visualizing emerging trends and transient patterns in scientific literature. $\mathrm{J} \mathrm{Am}$ Soc Inf Sci Technol. 2006;57(3):359-77.

[12] Chen C, Song IY, Yuan X, Zhang J. The thematic and citation landscape of Data and Knowledge Engineering (1985-2007). Data Knowl Eng. 2008;67(2):234-59.

[13] Chen C, Ibekwe-sanjuan F, Hou J, Chen C, Ibekwe-sanjuan F, Hou J, et al. The Structure and Dynamics of Co Citation Clusters: A Multiple Perspective Co-Citation Analysis. To cite this version: HAL Id: hal-00638091 The Structure and Dynamics of Co Citation Clusters: A Multiple Perspective Co Citation Analysis. 2011;

[14] Ran L, Chen X, Wang Y, Wu W, Zhang L, Tan X. Risk Factors of Healthcare Workers with Coronavirus Disease 2019: A Retrospective Cohort Study in a Designated Hospital of Wuhan in China. Clin Infect Dis. 2020;71(16):2218-21.

[15] Li Q, Guan X, Wu P, Wang X, Zhou L, Tong Y, et al. Early Transmission Dynamics in Wuhan, China, of Novel Coronavirus-Infected Pneumonia. N Engl J Med. 2020; 382(13):1199-207.

[16] Suzuki T, Hayakawa K, Ainai A, Iwata-Yoshikawa N, Sano $\mathrm{K}$, Nagata N, et al. Effectiveness of personal protective equipment in preventing severe acute respiratory syndrome coronavirus 2 infection among healthcare workers. J Infect Chemother [Internet]. 2021;27(1):120-2. Available from: https://doi.org/10.1016/j.jiac.2020.09.006
[17] Omidi L, Moradi G, Mostofi Sarkari N. Risk of COVID19 infection in workplace settings and the use of personal protective equipment. Work. 2020;66(2):377-8.

[18] Furuno JP, Krein S, Lansing B, Mody L. Health care worker opinions on use of isolation precautions in long-term care facilities. Am J Infect Control [Internet]. 2012;40(3):2636. Available from: http://dx.doi.org/10.1016/j.ajic.2011. 03.019

[19] Mhango M, Dzobo M, Chitungo I, Dzinamarira T. COVID-19 Risk Factors Among Health Workers: A Rapid Review. Saf Health Work [Internet]. 2020;11(3): 262-5. Available from: https://doi.org/10.1016/j.shaw.2020. 06.001

[20] Zhao Y, Xiang C, Wang S, Peng C, Zou Q, Hu J. Radiology department strategies to protect radiologic technologists against COVID19: Experience from Wuhan. Eur J Radiol [Internet]. 2020;127(April):108996. Available from: https://doi.org/10.1016/j.ejrad.2020.108996

[21] Tang L hua, Tang S, Chen X liang, Zhang S, Xiong $\mathrm{Y}$, Chen R, et al. Avoiding health worker infection and containing the coronavirus disease 2019 pandemic: Perspectives from the frontline in Wuhan. Int J Surg [Internet]. 2020;79(April):120-4. Available from: https://doi.org/ 10.1016/j.ijsu.2020.05.060

[22] Patil S, Moafa IH, Bhandi S, Jafer MA, Khan SS, Khan $\mathrm{S}$, et al. Dental care and personal protective measures for dentists and non-dental health care workers. Diseasea-Month [Internet]. 2020;66(9):101056. Available from: https://doi.org/10.1016/j.disamonth.2020.101056

[23] Cournoyer A, Grand'Maison S, Lonergan AM, Lessard J, Chauny JM, Castonguay V, et al. Oxygen Therapy and Risk of Infection for Health Care Workers Caring for Patients With Viral Severe Acute Respiratory Infection: A Systematic Review and Meta-analysis. Ann Emerg Med [Internet]. 2021;77(1):19-31. Available from: https://doi.org/10.1016/ j.annemergmed.2020.06.037

[24] Mossburg S, Agore A, Nkimbeng M, Commodore-Mensah Y. Occupational hazards among healthcare workers in africa: A systematic review. Ann Glob Heal. 2019;85(1): $1-13$.

[25] Xiao J, Fang M, Chen Q, He B. SARS, MERS and COVID19 among healthcare workers: A narrative review. J Infect Public Health [Internet]. 2020;13(6):843-8. Available from: https://doi.org/10.1016/j.jiph.2020.05.019

[26] Viswanath A, Monga P. Working through the COVID-19 outbreak: Rapid review and recommendations for MSK and allied heath personnel. J Clin Orthop Trauma [Internet]. 2020;11(3):500-3. Available from: https://doi.org/10.1016/ j.jcot.2020.03.014

[27] Yu J, Ding N, Chen H, Liu XJ, He W jie, Dai W cai, et al. Infection Control against COVID-19 in Departments of Radiology. Acad Radiol [Internet]. 2020;27(5):614-7. Available from: https://doi.org/10.1016/j.acra.2020.03.025

[28] Ing EB, Xu QA, Salimi A, Torun N. Physician deaths from corona virus (COVID-19) disease. Occup Med (Chic Ill). 2020;70(5):370-4.

[29] Macintyre CR, Seale H, Yang P, Zhang Y, Shi W, Almatroudi A, et al. Quantifying the risk of respiratory infection in healthcare workers performing high-risk procedures. Epidemiol Infect. 2014;142(9):1802-8.

[30] Zhang S, Guo M, Wu F, Xiong N, Ma Y, Wang Z, et al. Factors associated with asymptomatic infection in health-care workers with severe acute respiratory syndrome coronavirus 2 infection in Wuhan, China: a multicentre retrospective cohort study. Clin Microbiol Infect [Internet]. 
2020;26(12):1670-5. Available from: https://doi.org/ 10.1016/j.cmi.2020.08.038

[31] Wang X, Jiang X, Huang Q, Wang H, Gurarie D, NdeffoMbah M, et al. Risk factors of SARS-CoV-2 infection in healthcare workers: a retrospective study of a nosocomial outbreak. Sleep Med X [Internet]. 2020;2:100028. Available from: https://doi.org/10.1016/j.sleepx.2020.100028

[32] Elkholy AA, Grant R, Assiri A, Elhakim M, Malik MR, Van Kerkhove MD. MERS-CoV infection among healthcare workers and risk factors for death: Retrospective analysis of all laboratory-confirmed cases reported to WHO from 2012 to 2 June 2018. J Infect Public Health [Internet]. 2020;13(3):418-22. Available from: https://doi.org/ 10.1016/j.sleepx.2020.100028

[33] Bai Y, Wang X, Huang Q, Wang H, Gurarie D, Ndeffo-Mbah $\mathrm{M}$, et al. SARS-CoV-2 infection in health care workers: A retrospective analysis and model study. medRxiv. 2020;

[34] Chen B, Gu H, Wang X, Wang F, Peng Y, Ge E, et al. Prevalence and determinants of latent tuberculosis infection among frontline tuberculosis healthcare workers in southeastern China: A multilevel analysis by individuals and health facilities. Int J Infect Dis [Internet]. 2019;79:26-33. Available from: https://doi.org/10.1016/j.ijid.2018.11.010

[35] Piccoli L, Ferrari P, Piumatti G, Jovic S, Rodriguez BF, Mele F, et al. Risk assessment and seroprevalence of SARSCoV-2 infection in healthcare workers of COVID-19 and non-COVID-19 hospitals in Southern Switzerland. Lancet Reg Heal - Eur [Internet]. 2020;000(2020):100013. Available from: https://doi.org/10.1016/j.lanepe.2020.100013

[36] Vimercati L, De Maria L, Quarato M, Caputi A, Stefanizzi P, Gesualdo L, et al. COVID-19 hospital outbreaks: Protecting healthcare workers to protect frail patients. An Italian observational cohort study. Int J Infect Dis. 2021;102:532-7.

[37] Nishimura T, Ota M, Mori M, Fujiwara H, Takano Y, Kato S, et al. Risk of tuberculosis infection among health care workers and nursing students in Japan. J Infect Chemother [Internet]. 2018;24(11):921-4. Available from: https://doi.org/10.1016/j.jiac.2018.08.006https://doi.org/ 10.1016/j.jiac.2018.08.006

[38] Maltezou HC, Dedoukou X, Tsonou P, Tseroni M, Raftopoulos V, Pavli A, et al. Hospital factors associated with SARS-CoV-2 infection among healthcare personnel in Greece. J Hosp Infect [Internet]. 2021;109:40-3. Available from: https://doi.org/10.1016/j.jhin.2020.10.010

[39] Schwartz J, King CC, Yen MY. Protecting healthcare workers during the coronavirus disease 2019 (covid-19) outbreak: Lessons from Taiwan's severe acute respiratory syndrome response. Clin Infect Dis. 2020;71(15):858-60.

[40] Fryk JJ, Tong S, Marshall C, Rajkhowa A, Buising K, MacIsaac C, et al. Knowledge, attitudes and practices of healthcare workers within an Australian tertiary hospital to managing high-consequence infectious diseases. Infect Dis Heal [Internet]. 2020;(xxxx). Available from: https:// doi.org/10.1016/j.idh.2020.10.002

[41] Chung JS, Ling ML, Seto WH, Ang BSP, Tambyah PA. Debate on MERS-CoV respiratory precautions: Surgical mask or N95 respirators? Singapore Med J. 2014;55(6): 294-7.
[42] Loeb M, McGeer A, Henry B, Ofner M, Rose D, Hlywka $\mathrm{T}$, et al. SARS among Critical Care Nurses, Toronto. Emerg Infect Dis. 2004;10(2):251-5.

[43] Hellewell J, Abbott S, Gimma A, Bosse NI, Jarvis CI, Russell TW, et al. Feasibility of controlling COVID-19 outbreaks by isolation of cases and contacts. Lancet Glob Heal. 2020;8(4):e488-96.

[44] Bloomfield SF, Aiello AE, Cookson B, O'Boyle C, Larson EL. The effectiveness of hand hygiene procedures in reducing the risks of infections in home and community settings including handwashing and alcohol-based hand sanitizers. Am J Infect Control. 2007;35(10 SUPPL. 1).

[45] van Rensburg, D. Steyn F. Centre for Health Systems Research and Development Report 2007. 2007; (February 2013):2013.

[46] Kumakech E, Achora S, Berggren V, Bajunirwe F. Occupational exposure to HIV: A conflict situation for health workers. Int Nurs Rev. 2011;58(4):454-62.

[47] Mirtskhulava V, Whitaker JA, Kipiani M, Harris DA, Tabagari N, Owen-Smith AA, et al. Determinants of Tuberculosis Infection Control-Related Behaviors among Healthcare Workers in the Country of Georgia. Infect Control Hosp Epidemiol. 2015;36(5):522-8.

[48] Wang J, Zhou M, Liu F. Reasons for healthcare workers becoming infected with novel coronavirus disease 2019 (COVID-19) in China. J Hosp Infect [Internet]. 2020; 105(1):100-1. Available from: https://doi.org/10.1016/j. jhin.2020.03.002

[49] Lai J, Ma S, Wang Y, Cai Z, Hu J, Wei N, et al. Factors Associated With Mental Health Outcomes Among Health Care Workers Exposed to Coronavirus Disease 2019. JAMA Netw open. 2020;3(3):e203976.

[50] Su TP, Lien TC, Yang CY, Su YL, Wang JH, Tsai SL, et al. Prevalence of psychiatric morbidity and psychological adaptation of the nurses in a structured SARS caring unit during outbreak: A prospective and periodic assessment study in Taiwan. J Psychiatr Res. 2007;41(1-2):119-30.

[51] Salgado CD, Farr BM, Hall KK, Hayden FG. Influenza in the acute hospital setting. Lancet Infect Dis. 2002;2(3):145-55.

[52] Huang Q, Huo X, Ruan S. Optimal control of environmental cleaning and antibiotic prescription in an epidemiological model of methicillin-resistant Staphylococcus aureus infections in hospitals. Math Biosci [Internet]. 2019; 311(January):13-30. Available from: https://doi.org/10. 1016/j.mbs.2019.01.013

[53] Moed HF, Luwel M, Nederhof AJ. Towards research performance in the humanities. Libr Trends. 2001;50(3):498-520.

[54] Lopez-Leon S, Forero DiA, Ruiz-DIáz P. Recommendations for working from home during the COVID-19 pandemic (and beyond). Work. 2020;66(2):371-5.

[55] Dehghani F, Omidi F, Yousefinejad S, Taheri E. The hierarchy of preventive measures to protect workers against the COVID-19 pandemic: A review. Work. 2020;67(4):771-7.

[56] Nacoti M, Ciocca A, Giupponi A, Brambillasca P. At the Epicenter of the Covid-19 Pandemic and Humanitarian Crises in Italy: Changing Perspectives on Preparation and Mitigation. 2020;(Figure 1):1-5. 